\title{
Konseling Behavior dalam Meningkatkan Manajemen Diri Siswa Remaja
}

\author{
Siti Kholijah', Tadjoer Ridjal², Bakhrudin All Habsy² \\ ${ }^{1}$ SMP Budi Utomo Perak \\ ${ }^{2}$ Universitas Darul Ulum Jombang \\ Email Address: bakhrudin_bk@yahoo.com
}

Submitted: 2019-03-17, Revised: 2019-03-17, Accepted: 2019-06-25

\begin{abstract}
Self management is the process of specific steps consisting of planning, organizing, mobilizing and controlling needed to achieve the expected goals, so that individuals can do better. The design of this study was purposive sampling pretest-posttest control group design, which was analyzed using the T-Test. The population in this study were VIII grade students of Budi Utomo Perak Jombang Middle School with 49 students. The sample of this study was 6 students who were divided into experimental groups and control groups. The instruments in this study are self-management questionnaires. Based on the data analysis the results of the tcount are $r 0.985$ and the probability value (Sig. (2-tailed) is 0.381 with $d f=4$. Then the value is compared with the price of ttable at a significant level of 5\% two-party test with $d f=42,776$. thitung .985 is greater than t_table 2.776 and the probability value is 0.381 , it can be accounted for student management before and approved counseling of Middle School students. Of this study can be conveyed suggestions: (1) Teacher Guidance and Counseling, counseling behavior can be applied to improve student self-management Middle School and for the next researcher can use the use and other relevant techniques used that are used by researchers now.
\end{abstract}

Keywords: Behavior Counseling; Self Management

\begin{abstract}
Abstrak: Manajemen diri adalah proses langkah-langkah spesifik yang terdiri dari planning, organizing, actuating dan controlling yang diperlukan untuk mencapai tujuan yang diharapkan, sehingga dapat menjadikan individu yang lebih baik. Rancangan penelitian ini adalah purposive sampling pretest-posttest control group design, yang dianalisis menggunakan Uji-t. Populasi dalam penelitian ini adalah siswa kelas VIII SMP Budi Utomo Perak Jombang sebanyak 49 siswa. Sampel penelitian ini adalah 6 siswa yang dibagi menjadi kelompok eksperimen dan kelompok kontrol. Instumen dalam penelitian ini adalah angket manajemen diri. Berdasarkan analisis data hasil nilai thitung adalah r 0.985 dan angka probabilitas (Sig. (2-tailed) adalah 0.381 dengan $\mathrm{df}=4$. Selanjutnya nilai tersebut dibandingkan dengan harga $t_{\text {tabel }}$ pada taraf signifikan 5\% uji dua pihak dengan $\mathrm{df}=4$ sehingga diketahui harga $t_{\text {tabel }} 2,776$. Karena harga $t_{\text {hitung }} .985$ lebih besar dari $t_{\text {tabel }} 2,776$ dan nilai probabilitas adalah 0.381, maka dapat dikatakan bahwa manajemen diri siswa sebelum dan sesudah dilaksanakan konseling Behavior pada kelompok eksperimen terdapat perbedaan secara signifikan. Maka dapat disimpulkan bahwa konseling behavior efektif untuk meningkatkan manajemen diri siswa SMP. Dari penelitian tersebut dapat disampaikan saran yaitu Guru Bimbingan dan Konseling, konseling behavior dapat diterapkan untuk meningkatkan manajemen diri siswa SMP dan untuk peneliti berikutnya dapat menggunakan pendekatan dan teknik lainnya yang relevan selain yang telah digunakan oleh peneliti sekarang.
\end{abstract}

Kata Kunci: Konseling Behavior; Manajemen Diri

\section{Pendahuluan}

Sekolah Menengah Pertama merupakan salah satu bentuk satuan pendidikan dasar yang menyelenggarakan pendidikan tiga tahun setelah sekolah dasar. Pendidikan SMP berlandaskan dan menunjang tercapainya fungsi pendidikan nasional bagi pengembangan kemampuan dan bentukan watak serta peradaban bangsa yang bermartabat dalam rangka mencerdaskan kehidupan bangsa yang bertujuan untuk berkembangnya potensi peserta didik agar menjadi manusia yang beriman dan bertaqwa kepada Tuhan Yang Maha Esa, berakhlaq mulia, sehat, berilmu, cakap, kreatif, mandiri, dan menjadi manusia warga Negara yang demokratis serta bertanggung jawab (Indonesia, 2003). 
Secara psikologis, siswa SMP merupakan individu yang berada pada masa peralihan dari masa kanak-kanak menuju masa remaja. Pada fase remaja mengalami perubahan dalam sistem kerja hormon dalam tubuhnya dan hal ini memberi dampak baik pada bentuk fisik dan psikologis (Hurlock dalam Deshpande \& Chhabriya, 2013).

Menurut Habsy (Habsy, 2017b) setiap individu pasti akan mengalami transisi dalam kehidupan, namun pada kenyataannya para remaja tidak dapat sepenuhnya menjalani perubahan yang dialami, bahkan ketika perubahan bersifat positif. Masa remaja merupakan masa kritis bagi pertumbuhan dan perkembangan remaja dengan mudah memunculkan konflik dalam diri (Habsy, 2017a).

Menteri Pendidikan dan Kebudayaan Indonesia, amat prihatin dengan Indeks Integritas atau tingkat kejujuran Ujian Nasional (UN) yang masih rendah. Bahkan beliau menyebut, korupsi yang sekarang banyak terjadi, berawal dari tindakan contek-mencontek. Dari data yang dikumpulkan Kemendikbud, secara umum, indeks integritas nasional saat ini tercatat masih cukup rendah, atau masih berada di bawah angka 70 (Vivanews, 2018). Selama tahun 2015, pelajar yang membolos di kawasan Jatinom, Klaten, rata-rata mencapai 10 siswa per bulan. Jumlah tersebut lebih sedikit dibandingkan tahun 2014 yang berkisar 20 siswa per bulan (Solopos, 2018).

Berdasarkan fakta di lapangan tersebut menegaskan rendahnya kemampuan individu dalam menata perilaku untuk mengarahkan dan mengelola dirinya agar dapat mencapai kemandirian dan hidupnya berjalan dengan produktif. Hal ini dipandang sebagai rendahnya manajemen diri pada remaja. Menurut Davis, manajemen diri merupakan suatu upaya untuk mengelola perilaku sendiri, yang meliputi proses pengelolaan diri dalam mengendalikan tingkah laku(Davis, Leveille, Favaro, \& LoGerfo, 1998). Menurut Rahmadani manajemen diri adalah suatu proses yang terdiri dari planning, organizing, actuating dan controlling yang dilakukan untuk mencapai tujuan yang ditentukan dalam diri individu (Rahmadani, Arlizon, \& Saam, 2017).

Individu dengan manajemen diri tinggi mampu mengelola dirinya dan mengarahkan prilaku-prilakunya ke arah yang positif. Menurut Yates menejemen diri merupakan upaya yang mendorong individu untuk mampu mengarahkan perilaku-perilakunya sendiri dengan tanggung jawab atas tindakannya untuk mencapai kemajuan diri (Yates, 1985).

Berdasarkan studi pendahuluan dengan konselor, yang dilakukan oleh peneliti melalui observasi dan wawancara, di SMP Budi Utomo Perak Jombang, menyebutkan bahwa ada beberapa siswa yang menampakan kriteria manajemen diri rendah. Terkait dalam kegitan ulangan harian, siswa menunjukkan ketidaksiapan siswa dalam mengerjakan soal. Siswa tersebut kurang memiliki kesadaran untuk melaksanakan kegiatan belajar, sehingga mereka baru akan melakukan kegiatan belajar apabila diingatkan oleh orang lain, siswa kurang mampu mengatur waktu secara efektif, siswa sering menunda-nunda tugas sekolah, membolos, datang terlambat, tidur saat jam pelajaran, Selain itu adanya siswa mencontek pada saat ujian atau ulangan. Hal tersebut juga menunjukkan manajemen diri yang rendah.

Manajemen diri dalam penelitian ini merupakan suatu upaya pengendalian diri terhadap pikiran, ucapan dan perbuatan yang dilakukan sehingga mendorong pada penghindaran diri terhadap hal-hal yang tidak baik dan meningkatkan perbuatan yang baik dan benar. Siswa yang manajemen dirinya rendah mudah terpengaruh oleh keadaan maupun lingkungan yang berubah-rubah. Berbeda dengan siswa yang memiliki manajemen diri tinggi, dia akan memiliki prinsip dalam hidupnya tidak akan mudah terpengaruh dengan keadaan karena telah memiliki manajemen diri yang baik. Dalam penelitian ini manajemen diri diukur dengan menggunakan angket manajemen diri berdasarkan teori Albert Bandura yang terdiri dari indikator observasi diri, penilaian tingkah laku, standar pribadi, respon diri (selfresponse)(Lorig et al., 2001). 
Untuk mengembangkan manajemen diri secara efektif maka perlu dilakukan langkahlangkah dengan tahapan yang sistematis menggunakan prosedur yang jelas, salah satu langkah yang ditempuh guru Bimbingan dan Konseling adalah konseling sebagai upaya penyelesaian masalah. Menurut Habsy, para pengguna layanan konseling di Indonesia diharapkan mampu mempelajari dan mempraktikkan teori dan pendekatan, serta merumuskan paradigma baru dengan bukti-bukti empiris dan rasional. Konseling dalam setting pendidikan adalah upaya pedagogis yang dilakukan konselor untuk menciptakan kondisi optimum bagi perkembangan individu (Habsy, 2017a).

Salah satu pendekatan konseling yang dipilih adalah pendekatan konseling behavior. Menurut Bootzin konseling behavior dikenal juga dengan modifikasi perilaku yang dapat diartikan sebagai tindakan yang bertujuan untuk mengubah perilaku. Modifikasi perilaku dapat pula diartikan sebagai usaha menerapkan prinsip-prinsip belajar pada belajar pada perilaku manusia(Setiyawan, 2013).

Konseling Behavior dalam penelitian ini adalah suatu upaya-upaya pengubahan tingkah laku individu yang ditentukan oleh modifikasi perilaku dalam situasi hidupnya. Teknik Konseling Behavior yang digunakan untuk meningkatkan manajemen diri siswa adalah penguatan positif, terapi aversi (aversiv therapy) dan disensitisasi sistematis. Tahap tahap konseling behavioral memiliki empat tahap yaitu melakukan (assessment), menentukan tujuan (goalsetting), mengimplementasikan teknik (technique implementation), dan evaluasi dan mengakhiri konseling (evaluation termination). Pelaksanaan prosedur-prosedur konseling behavior untuk meningkatkan manajemen diri divisualkan pada gambar 1 ., dibawah ini:

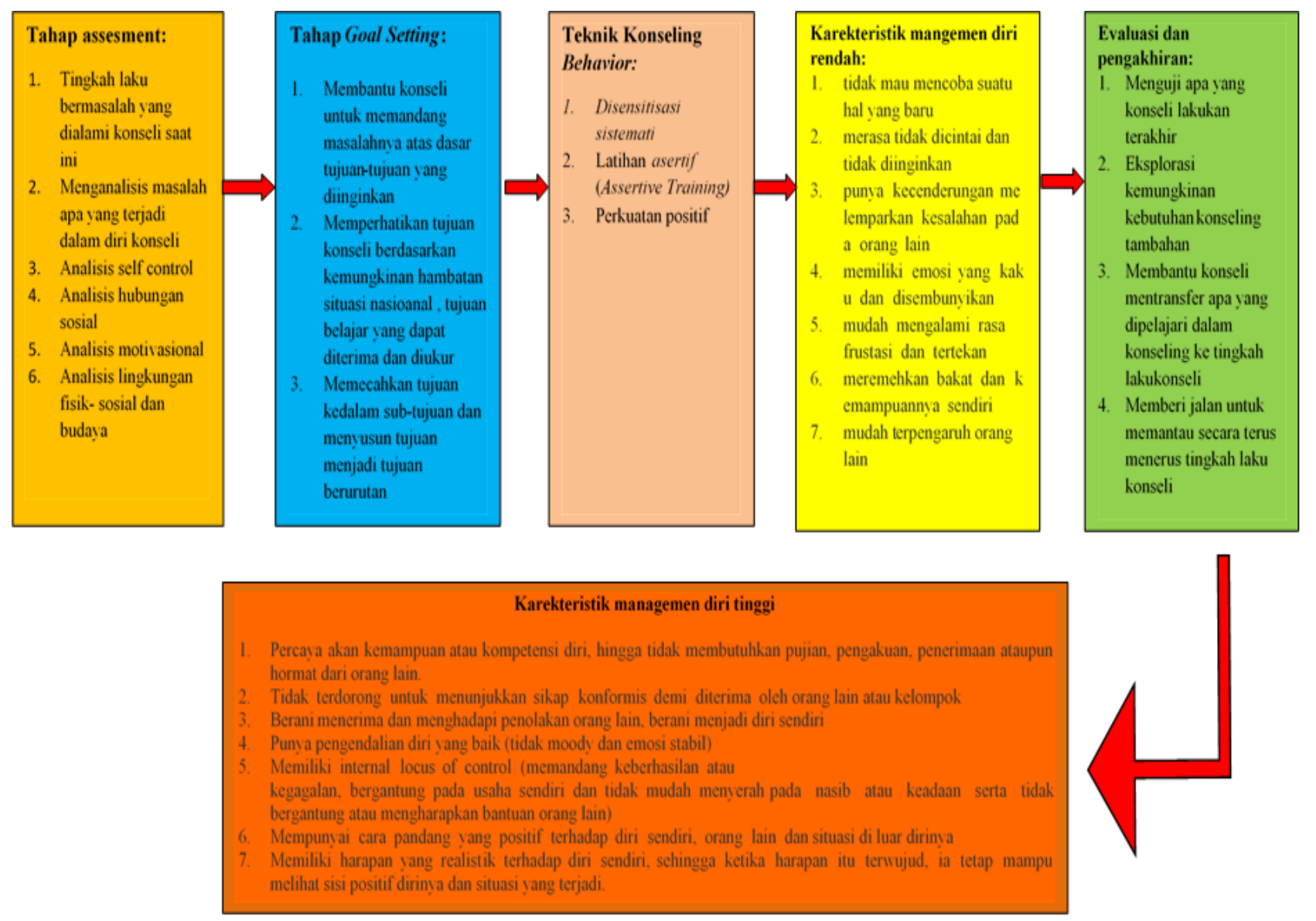

Gambar 1. Prosedur-Prosedur Konseling Behavior untuk Meningkatkan Manajemen Diri 


\section{Metode Penelitian}

Desain atau rancangan penelitian merupakan suatu proses yang diperlukan dalam perencanaan dan pelaksanaan sebuah penelitian (Habsy, Hidayah, Lasan, \& Muslihati, 2017). Jenis penelitian yang dipakai oleh peneliti dalam penelitian ini adalah penelitian kuantitatif, yang merupakan jenis penelitian utama untuk mengetahui keefektifan konseling Behavior untuk meningkatkan manajemen diri siswa, maka penelitian ini termasuk penelitian eksperimen. Menurut Arifin penelitian eksperimen merupakan cara praktis untuk mempelajari sesuatu dengan mengubah-ubah kondisi dan mengamati pengaruhnya terhadap hal lainnya. Tujuannya adalah untuk mengetahui pengaruh atau hubungan sebab akibat dengan cara membandingkan hasil kelompok eksperimen yang diberikan perlakuan dengan kelompok kontrol yang tidak diberikan perlakuan (Arifin, 2011). Penelitian ini merupakan penelitian quasi experimental dengan nonequivalent group pretest-posttest. Desain penelitian ini dapat digambarkan sebagai berikut :

Tabel 1. Desain Penelitian

\begin{tabular}{llll}
\hline Kelompok & Pre test & Perlakuan & Post test \\
\hline Eksperimen $(\mathrm{E})$ & O1 & X1 & O3 \\
\hline Kontrol $(\mathrm{K})$ & O2 & X2 & O4 \\
\hline
\end{tabular}

Keterangan :

$\mathrm{O}_{1} \quad$ : Pre test pada kelompok eksperimen

$\mathrm{O}_{3}$ : Post test pada kelompok eksperimen

$\mathrm{O}_{1}$ : Pre test pada kelompok kontrol

$\mathrm{O}_{3}$ : Post test pada kelompok kontrol

$\mathrm{X}_{1} \quad$ : layanan konseling behavior

$\mathrm{X}_{2}$ : layanan konseling tanpa teknik

Untuk memperjelas desain penelitian ini dilakukan langkah-langkah sebagai berikut:

1. Melakukan pretest, yaitu memberikan angket manajemen diri berdasarkan teori Albert Bandura yang terdiri dari indikator observasi diri, penilaian tingkah laku, standar pribadi, respon diri (selfresponse) kepada populasi penelitian sebelum diberikannya treatment (Lorig et al., 2001).

2. Membagi menjadi dua kelompok, yang masuk kelompok eksperimen dan kelompok kontrol, pada kelompok kontrol diberikan konseling kelompok tanpa teknik sedangkan pada kelompok eksperimen diberikan konseling Behavior.

3. Melakukan posttest pada dua kelompok, antara kelompok eksperimen dan kelompok kontrol hal ini bertujuan agar dapat membandingkan tingkat manajemen diri siswa sebelum dan sesudah diberikan treatment, dan membedakan hasil antara kelompok eksperimen dan kelompok kontrol.

Untuk mendukung keefektifan Konseling Behavior untuk meningkatkan manajemen diri pada kelompok eksperimen, peningkatan tersebut dikontrol dengan hasil yang dicapai oleh kelompok kontrol. Secara visual, kerangka kerja penelitian Konseling Behavior untuk meningkatkan manajemen diri, dapat dilihat dalam gambar 2., sebagai berikut: 


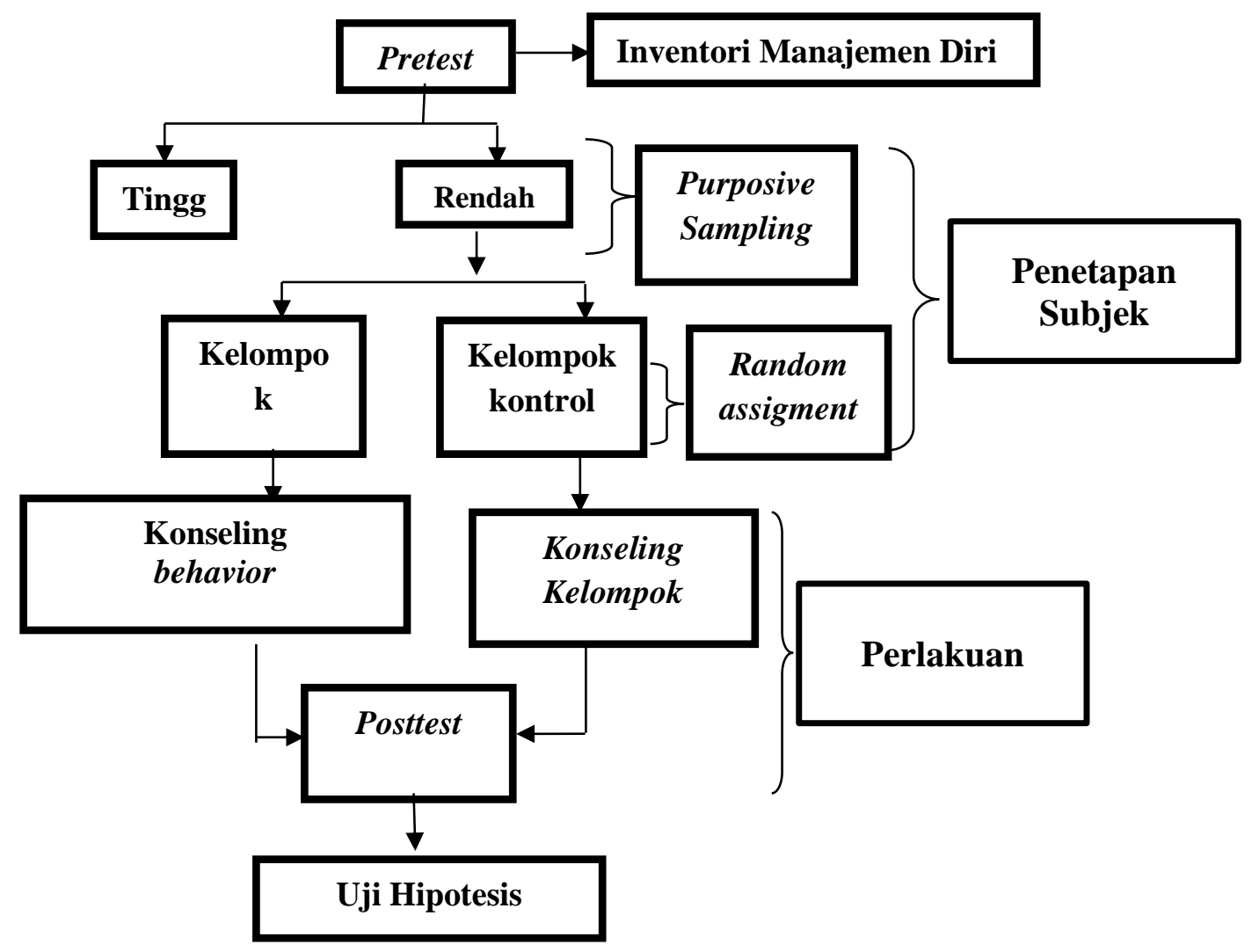

Gambar 2. Kerangka Kerja Penelitian

(Diadaptasi dari Habsy, 2018)

\section{Hasil dan Pembahasan}

Diskripsi Data Penelitian

Pelaksanaan penelitian eksperimen ini dilaksanakan dalam 6 kali pertemuan, pada pertemuan pertama diberikan pretest, 4 pertemuan berikutnya diberikan treatment dan pada akhir pertemuan dilakukan posttest.

1. Hasil Pretest

Hasil Pretest manajemen diri siswa yang telah dilakukan dapat dilihat pada tabel 2 ., berikut ini:

Tabel 2. Descriptive Statistics

\begin{tabular}{|lccccc}
\hline & N & Minimum & Maksimum & Mean & $\begin{array}{c}\text { Std. } \\
\text { Dceviation }\end{array}$ \\
\hline Pretest & 49 & 152,201 & 178,499 & 165,35 & 13,14911 \\
\hline Valid N & 49 & & & & \\
\hline
\end{tabular}




\begin{tabular}{|l|l|l|l|l|l|}
\hline (listwise) & & & & & \\
\hline
\end{tabular}

Dari tabel 2 diatas, maka dapat diketahui skor maksimal yang diperoleh dari pretest adalah 178, 499 dan skor minimalnya adalah 152, 201 rata-rata (Mean) adalah 165, 35 dan standar deviasi adalah 13, 14911. Dari data diatas selanjutnya dilakukan pengkategorian dengan pembagian pengkategorian sebagai berikut:

a. Kategori Tinggi : Mean skor $+1 \mathrm{SD}$

$: 165,35+13,149$

: 178,499 (179 keatas tinggi)

b. Kategori Sedang : Mean skor - 1 SD sampai Mean skor + 1 SD

: $165,35-13,149$ sampai $165,35+13,149$

: 152, 201 sampai 178,499

c. Kategori Rendah : Mean skor - 1SD

$: 165,35-13,149$

$: 152,201$

Dengan demikian, hasil pretest manajemen diri rendah siswa dapat dilihat pada tabel 3., berikut ini:

Tabel 3. Hasil Pretest Manajemen Diri Rendah

\begin{tabular}{|c|c|c|c|}
\hline No & Nama & Skor & Kategori \\
\hline 1 & DES & 144 & Rendah \\
\hline 2 & FKN & 143 & Rendah \\
\hline 3 & HF & 152 & Rendah \\
\hline 4 & INH & 148 & Rendah \\
\hline 5 & YFS & 151 & Rendah \\
\hline 6 & FFH & 127 & Rendah \\
\hline
\end{tabular}

Selanjutnya, data tersebut dapat diklarifikasikan dalam tabel 4., berikut ini:

Tabel 4. Klasifikasi Jawaban Responden Terhadap Angket Manajemen Diri

\begin{tabular}{|l|l|l|l|l|}
\hline No & Kelas interval & Frekuensi & Prosentase & Keterangan \\
\hline 1 & 178,499 keatas & 16 & $15 \%$ & Tinggi \\
\hline 2 & $\begin{array}{l}152,201 \text { sampai } \\
178,499\end{array}$ & 27 & $75 \%$ & Sedang \\
\hline 3 & 152,201 kebawah & 6 & $10 \%$ & Rendah \\
\hline & Jumlah & 49 & $100 \%$ & \\
\hline
\end{tabular}

Dari tabel diatas dapat diketahui bahwa jawaban dari responden untuk variabel manajemen diri yang terbesar adalah 27 dengan kriteria sedang. Dengan demikian dapat disimpulkan secara umum, manajemen diri siswa kelas VIII termasuk dalam kategori "sedang".

Sesuai dengan tujuan bimbingan dan konseling adalah membantu siswa yang memiliki permasalahan khususnya dan siswa pada umumnya. Maka beberapa siswa yang memiliki 
permasalahan dengan manajemen diri rendah berdasarkan hasil pretest dalam penelitian ini akan diambil 6 siswa yang nilai pretestnya rendah, kemudian dibagi menjadi 2 kelompok, 1 kelompok kontrol yang diberikan layanan konseling tanpa teknik dan satu kelompok eksperimen yang diberikan layanan konseling Behavior. Adapun 6 siswa yang memiliki skor terendah dan sudah dibagi menjadi 2 kelompok dapat dilihat dalam tabel 5., berikut:

Tabel 5. Hasil Pretest Kelompok Eksperimen dan Kelompok Kontrol

\begin{tabular}{|l|l|l|l|l|l|l|l|}
\hline \multicolumn{4}{|c|}{ Kelompok eksperimen } & \multicolumn{4}{c|}{ Kelompok kontrol } \\
\hline No & $\begin{array}{c}\text { Nama } \\
\text { konseli }\end{array}$ & Skor & Kategori & No & $\begin{array}{c}\text { Nama } \\
\text { konseli }\end{array}$ & Skor & Kategori \\
\hline 1. & DES & 144 & Rendah & 1. & HF & 152 & Rendah \\
\hline 2. & FKN & 143 & Rendah & 2. & YFS & 151 & Rendah \\
\hline 3. & INH & 148 & Rendah & & & & \\
\hline 4. & FFH & 127 & Rendah & & & & \\
\hline
\end{tabular}

2. Hasil Post Test

Pelaksanaan posttest dimaksudkan untuk membandingkan ada tidaknya perbedaan Manajemen Diri sebelum dan sesudahnya diberikan layanan konseling behavior. Selain itu, pemberian posttest juga bertujuan untuk membedakan hasil antara kelompok eksperimen dan kelompok kontrol. Posttest dilakukan dengan memberikan angket manajemen diri kepada kedua kelompok kontrol dan eksperimen. Hasil posttest tersebut dapat dilihat pada tabel 6. , berikut ini:

Tabel 6. Hasil Posttest Manajemen Diri antara Kelompok Kontrol dan Kelompok Eksperimen

\begin{tabular}{|l|l|l|l|l|l|}
\hline No & $\begin{array}{l}\text { Kelompok } \\
\text { Kontrol }\end{array}$ & Skor & No & $\begin{array}{l}\text { Kelompok } \\
\text { Eksperimen }\end{array}$ & Skor \\
\hline 1 & YFS & 176 & 1 & FFH & 183 \\
\hline 2 & HF & 161 & 2 & INH & 182 \\
\hline & & & 3 & FKN & 180 \\
\hline & & & 4 & DSE & 182 \\
\hline
\end{tabular}

Setelah semua data terkumpul sesuai dengan metode yang telah digunakan, maka langkah selanjutnya adalah menganalisis data. Analisis data digunakan untuk mengetahui hasil akhir dari penelitian yang dilakukan dengan cermat dan teliti. Dalam penelitian ini yang digunakan untuk menganalisis data adalah menggunakan Uji t-test. Data hasil pretest dan posttest antara kelompok kontrol dan kelompok eksperimen dapat dilihat pada tabel 7 ., berikut ini:

Tabel 7. Hasil Pre test dan Post test antara Kelompok Eksperimen dan Kelompok Kontrol

\begin{tabular}{|l|l|l|l|l|l|l|l|}
\hline Nama & Pretest & posttest & Beda & Nama & pretest & Posttest & Beda \\
\hline DES & 144 & 184 & 40 & INH & 148 & 182 & 34 \\
\hline
\end{tabular}




\begin{tabular}{|l|l|l|l|l|l|l|l|}
\hline FKN & 143 & 180 & 37 & YFS & 151 & 176 & 25 \\
\hline HF & 152 & 161 & 9 & FFH & 127 & 183 & 56 \\
\hline
\end{tabular}

Selanjutnya data tersebut diolah dengan menggunakan program spss 20,00 for windows dan dapat dilihat ditabel berikut ini:

Tabel 8. Group Statistics

\begin{tabular}{|c|c|c|c|c|}
\hline $\begin{array}{c}\text { Group } \\
\text { Statistics }\end{array}$ & Jenis Kelompok & Mean & $\begin{array}{c}\text { Std. } \\
\text { Deviation }\end{array}$ & Std. error mean \\
\hline $\begin{array}{c}\text { Manajemen } \\
\text { diri }\end{array}$ & Eksperimen & 181,75 & 1.258 & .629 \\
\cline { 2 - 5 } & Kontrol & 168,50 & 10,607 & 7,500 \\
\hline
\end{tabular}

Dari tabel 8., dapat diketahui mean (rata-rata) dari kelompok kontrol adalah sebesar 168,50, sedangkan mean ( rata-rata) dari kelompok eksperimen adalah 181,75 standar deviasi untuk kelompok kontrol adalah 10, 607 sedangkan standar deviasi untuk kelompok eksperimen adalah 1.258. standar error untuk mean kelompok kontrol adalah 7,500 sedangkan standar error mean untuk kelompok eksperimen .629.

Dari data tersebut, selanjutnya dilakukan pengujian t-test (independent sample test) menggunakan program spss 20,00 for windows. Hasil penelitian ini dapat dilihat pada tabel 9 berikut ini:

Tabel 9. Independent Samples Test

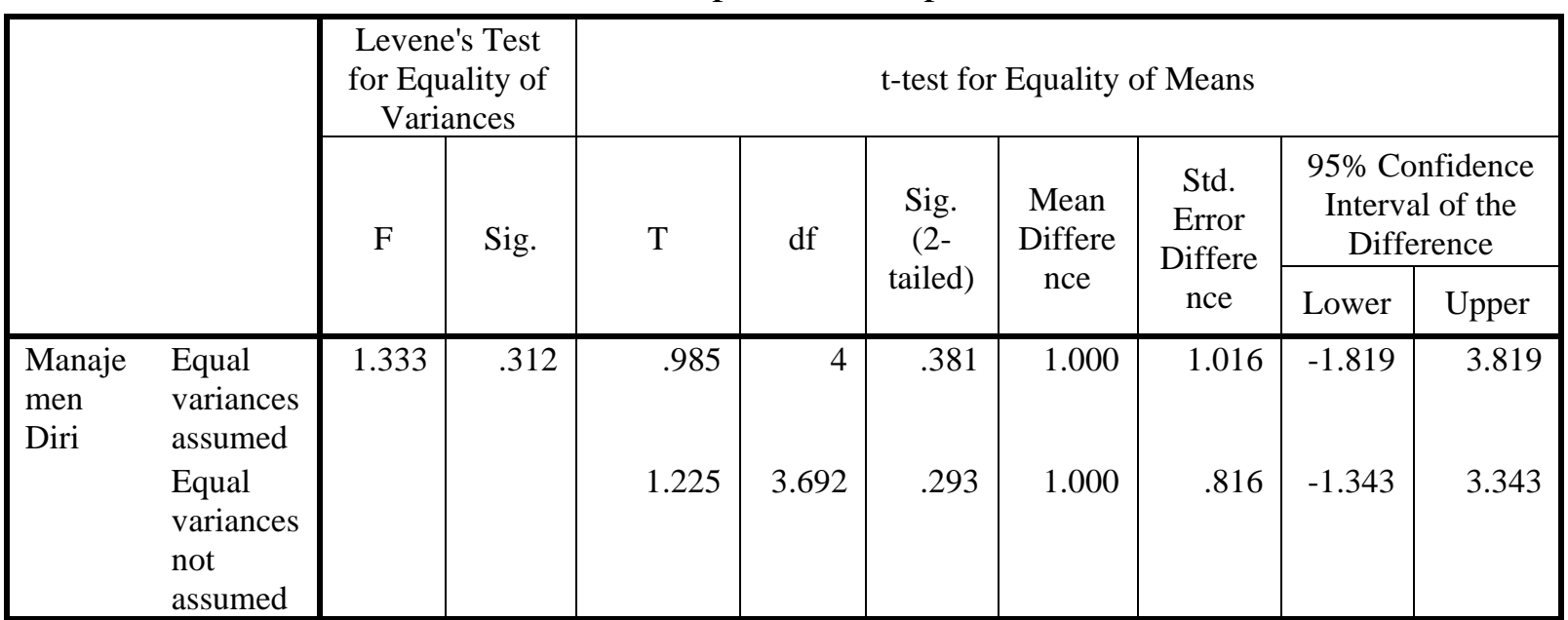

Dari perhitungan levene's test dapat dilihat angka signifikasi sebesar 0, 312 jika dibandingkan dengan pedoman pengambilan keputusan, maka terlihat bahwa angka 0,312 lebih besar dari 0,05 yang berarti bahwa hipotesis nihil diterima sehingga dapat disimpulkan bahwa varians populasi identik/homogen. Oleh karena hipotesis yang dipakai adalah bahwa kedua varians populasi identik/homogen, maka yang dijadikan pedoman utuk analisis lebih lanjut adalah hasil yang terdapat pada Equal variances assumed.

Hasil analisis Uji-t yang juga terdapat pada tabel 4.8, pada tabel tersebut diketahui thitung adalah sebesar 0.985 dan angka probabilitas (Sig. (2-tailed) adalah 0.381 dengan $\mathrm{df}=4$. 
Selanjutnya harga tersebut dibandingkan dengan harga $t_{\text {tabel }}$ pada taraf signifikan $5 \%$ uji dua pihak dengan $\mathrm{df}=4$ sehingga diketahui harga $t_{\text {tabel }} 2,776$. Karena harga $t_{\text {htung }} .985$ lebih besar dari $t_{\text {tabel }} 2,776$ dan nilai probabilitas adalah 0.381 , maka dapat dikatakan bahwa manajemen diri siswa sebelum dan sesudah dilasanakan konseling Behavior pada kelompok eksperimen terdapat perbedaan secara signifikan, dengan kata lain konseling Behavior efektif untuk meningkatkan manajemen diri siswa SMP.

Untuk mengetahui diterima atau tidaknya sebuah hipotesis dalam penelitian adalah:

a. $H_{a}$ : Pelaksanaan Layanan Konseling Behavior efektif dalam meningkatkan Manajemen Diri siswa SMP

b. $H_{O} \quad$ : Pelaksanaan Layanan Konseling Behavior tidak efekfif dalam meningkatkan Manajemen Diri Siswa SMP. Adapun kriteria pengujian hipotesis sebagai berikut:

- Terima $H_{O} t_{\text {hitung }}<t_{\text {tabel }}$ : dengan kata lain $H_{a}$ ditolak

- Tolak $H_{O} t_{\text {hitung }}<t_{\text {tabel }}$ : dengan kata lain $H_{a}$ diterima

Dari hasil SPSS 20,00 for windows diketahui $t_{\text {hitung }}$ adalah sebesar .985 dan angka Probabilitas (Sig.(2-tailed) adalah 0.381dengan $\mathrm{df}=4$.

Pemberian layanan konseling behavior merupakan salah satu langkah untuk meningkatkan manajemen diri siswa SMP. Konseling behavior siswa diajak untuk dapat memanajemen dirinya ke arah yang lebih baik.

Gambaran tentang keefektifan konseling behavior untuk meningkatkan manajemen diri siswa pada penelitian ini dapat dilihat dari diterimanya hipotesis kerja $\left(H_{a}\right)$ yang menyatakan bahwa "pelaksanaan layanan konseling behavior efektif untuk meningkatkan manajemen diri siswa SMP diterima.

Secara garis besar, tahapan-tahapan yang dilakukan peneliti dalam pemberian layanan konseling behavior meliputi:

a. Tahap awal

Pada pertemuan pertama, kegiatan yang dilakukan adalah siswa dan konselor berkenalan untuk keakraban dan pembentukan hubungan. Bertujuan untuk mengungkapkan kesuksesan dan kegagalannya, kekuatan dan kelemahannya, pola hubungan interpersonal,tingkah laku penyesuaian dan area masalahnya. Tahap ini tujuannya untuk menentukan apa yang akan konseli lakukan saat ini. Pada tahap awal ini terdapat informasi yang dapat digali yaitu tingkah laku yang dialami konseli saat ini, menganalisis masalah apa yang ada pada konseli, analisis self control, analisis hubungan sosial, analisis motivasi, analisis lingkungan, fisik-sosial dan budaya. Dalam hal ini konselor melakukan analisis dengan menggunakan model ABC (Anteceden event, Belive, Emotional Consequence)

b. Tahap Pertengahan

Memberikan bantuan kepada konseli untuk memandang masalahnya atas dasar tujuantujuan yang diinginkan, memperhatikan tujuan konseli berdasarkan kemungkinan hambatan situasional tujuan belajar yang dapat diterima dan dapat diukur, memecahkan tujuan ke dalam sub-tujuan dan menyusun tujuan menjadi yang berurutan.

c. Tahap Akhir

Pertemuan kedua adalah pertemuan terakhir dari rangkaian proses konseling behavior. Dalam pertemuan ini konselor dan konseli menentukan dan melaksanakan teknik konseling yang digunakan untuk mencapai tingkah laku yang diinginkan yang menjadi tujuan konseling. Konselor dan konseli secara bersama-sama mengevaluasi implementasi dari teknik 
yang telah dilakukan serta menentukan lamanya intervensi dilaksanakan, sampai tingkah laku menetap sesuai dengan yang diharapkan.

Dari pelaksanaan konseling behavior tersebut, ditemukan beberapa perubahan sikap dari konseli. DSE( Konseli 1) skor pretest manajemen diri siswa yang diperoleh DSE adalah 144 yang termasuk dalam kategori rendah. DSE sebenarnya merupakan anak yang pandai, tetapi dia kurang bisa memanajemen dirinya, hal ini dikarenakan dia belum bisa datang kesekolah tepat waktu sering kali terlambat dengan alasan bermacam-macam, terkadang pada saat jam pelajaran anak tersebut sering izin ke belakang padahal dia merasa tidak menyukai pelajaran yang diberikan oleh guru mata pelajaran tertentu.

Selama proses konseling yang telah dilaksanakan, ada beberapa perubahan yang terjadi padanya. Yaitu konseli mulai datang ke sekolah tepat waktu dia juga berusaha memahami pelajaran yang tadinya dia tidak sukai, karena dengan adanya perubahan itu konseli merasa senang jika akan berangkat ke sekolah maupun akan melaksanakan proses belajar mengajar di kelas tersebut. Setelah mengikuti konseling behavior selama dua kali pertemuan konseli mendapat skor posttest sebesar 184 yang termasuk kategori tinggi. Dengan peningkatan skor 40 .

FKN (Konseli II) skor pretest manajemen diri siswa yang diperoleh FKN adalah 143 termasuk dalam kategori rendah. Masalah manajemen diri FKN kurang bisa membagi waktu antara kegiatan yang ada di pondok maupun sekolah, dia merasa kesulitan dalam membagi waktu. Terkadang karena merasa capek pada saat sekolah sehingga tidak bisa mengikuti kegiatan yang ada di pondok. Oleh sebab itu dia merasa malas mengikuti kegiatan yang ada di pondok dikarena sudah merasa capek dan lelah mengikuti kegiatan di sekolah.

Selama mengikuti konseling behavior banyak perubahan yang terjadi padanya, FKN membuat jadwal untuk dirinya sendiri, yaitu waktu-waktu kegiatan yang ada di pondok maupun sekolah sehingga konseli tersebut dapat membagi waktunya antara kegiatan sekolah dan juga pondok. Setelah mengikuti konseling behavior selama dua kali pertemuan, FKN mendapatkan skor posttest sebesar 180. Yang termasuk kategori tinggi. Dengan kenaikan skor 37.

INH (Konseli III) skor pretest manajemen diri siswa yang diperoleh adalah 148 yang termasuk dalam kategori rendah. INH adalah konseli yang malas mengikuti pelajaran olahraga, dia merasa pelajaran olahraga tidak begitu penting dalam penilaian. Selain itu pelajaran olahraga tidak menyenangkan karena setelah pelajaran olahraga selesai anak-anak harus ganti baju terlebih baru boleh mengikuti pelajaran berikutnya. Itu menjadi alasannya tidak menyukai pelajaran olahraga.

Setelah mengikuti konseling behavior selama dua kali pertemuan, konseli merasa ada perubahan pada dirinya INH mulai mengikuti jika ada kegiatan olahraga dikelasnya. Dia mulai berfikir bahwa teman-temanya banyak yang menyukai pelajaran olah raga mengapa dia tidak, lama kelamaan dia mulai terbiasa. Pada saat dilakukan posttest konseli tersebut mendapatkan skor 180 yang masuk pada kategori tinggi yang menunjukan kenaikan skor 32 .

FFH (Konseli IV) skor pretest manajemen diri siswa yang diperoleh FFH adalah 127 yang termasuk kategori rendah. FFH mempunyai permasalahan pada manajemen dirinya yaitu malas mengerjakan PR di rumah sehingga jika sudah sampai di sekolah dia menunggu contekan dari temannya yang sudah mengerjakan PR di rumah. Dia mengatakan jika di rumah tidak ada teman untuk belajar bersama. Sehingga dia merasa malas jika ada PR yang diberikan oleh guru mata pelajaran pada saat itu.

Dengan adanya layanan konseling behavior FFH merasa ada yang memperhatikan dan memotivasi dia agar dapat merubah kebiasaanya tersebut. Setelah diadakan konseling behavior selama dua kali pertemuan maka posttest yang didapatkannya yaitu 183 yang termasuk kategori tinggi, dan mengalami peningkatan 56. 


\section{Simpulan dan Saran}

Berdasarkan hasil penelitian dan pembahasan maka dapat disimpulkan bahwa hasil pre test Konseling Behavior efektif untuk meningkatkan manajemen diri siswa SMP, hal ini dapat diketahui thitung adalah sebesar 0.985 dan angka probabilitas (Sig. (2-tailed) adalah 0.381 dengan $\mathrm{df}=4$. Selanjutnya harga tersebut dibandingkan dengan harga $t_{\text {tabel }}$ pada taraf signifikan 5\% uji dua pihak dengan $\mathrm{df}=4$ sehingga diketahui harga $t_{\text {tabel }} 2,776$. Karena harga $t_{\text {thung }} .985$ lebih besar dari $t_{\text {tabel }} 2,776$ dan nilai probabilitas adalah 0.381 , maka demikian dalam penelitian ini dapat disimpulkan bahwa pelaksanaan layanan konseling behavior efektif untuk meningkatkan manajemen diri siswa remaja.

Berdasarkan pada hasil penelitian dan simpulan hasil peneliti, diajukan beberapa saran sebagai berikut:

1. Bagi Guru Bimbingan dan Konseling

Hendaknya perlu meningkatkan pelayanan bimbingan dan konseling di sekolah untuk mengoptimalkan manajemen diri siswa terutama siswa SMP yang dengan salah satunya dapat diberikan layanan konseling behavior.

2. Bagi Peneliti Selanjutnya

Penelitian ini menggunakan pendekatan konseling behavior dengan teknik desensitisasi sistematis, latihan asertif, perkuatan positif, maka peneliti selanjutnya dapat menggunakan pendekatan dan teknik lain yang lebih relevan.

\section{Daftar Pustaka}

Arifin, Z. (2011). Penelitian pendidikan metode dan paradigma baru. Bandung: PT Remaja Rosdakarya.

Davis, C., Leveille, S., Favaro, S., \& LoGerfo, M. (1998). Benefits to volunteers in a community-based health promotion and chronic illness self-management program for the elderly. Journal of Gerontological Nursing, 24(10), 16-23.

Habsy, B. A. (2017a). Filosofi Ilmu Bimbingan dan Konseling Indonesia. Jurnal Pendidikan (Teori Dan Praktik), 2(1), 1. https://doi.org/10.26740/jp.v2n1.p1-11

Habsy, B. A. (2017b). Model Konseling Kelompok Cognitive Behavior untuk Meningkatkan Self Esteem Siswa Smk. Perspektif Ilmu Pendidikan, 31(1), 21. https://doi.org/10.21009/PIP.311.4

Habsy, B. A., Hidayah, N., Lasan, B. B., \& Muslihati, M. (2017). A literature review of indonesian life concept linuwih based on the teachings of adiluhung Raden Mas Panji Sosrokartono. In 3rd International Conference on Education and Training (ICET 2017). Atlantis Press.

Indonesia, R. (2003). Undang-undang Republik Indonesia nomor 20 tahun 2003 tentang sistem pendidikan nasional. Jakarta: Pemerintah Republik Indonesia.

Lorig, K. R., Ritter, P., Stewart, A. L., Sobel, D. S., Brown Jr, B. W., Bandura, A., ... Holman, H. R. (2001). Chronic disease self-management program: 2-year health status and health care utilization outcomes. Medical Care, 1217-1223.

Rahmadani, H., Arlizon, R., \& Saam, Z. (2017). Hubungan Manajemen Diri dengan Prestasi Belajar Mahasiswa Bimbingan Konseling Semester IV Universitas Riau. Jurnal Online Mahasiswa Fakultas Keguruan Dan Ilmu Pendidikan Universitas Riau, 4(2), 1-9.

Setiyawan. (2013). Hubungan Self Manajemen Dan Self Compotence Dengan Perilaku Prokrastinasi Akademik Siswa. Yogyakarta: . Skripsi Tidak Diterbitkan. Yogyakarta. 
Universitas Negeri Yogyakarta.

Yates, B. T. (1985). Self-management. California: Wadsworth Publishing Company. 